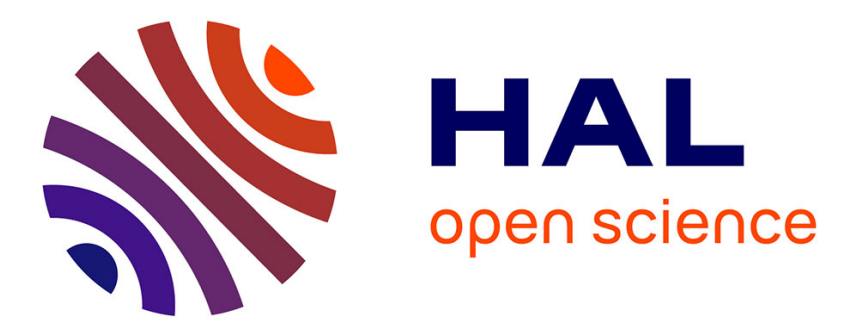

\title{
An Information Management Perspective of Supplier Selection Process in Manufacturing Networks
}

Dario Messina, Ana Cristina Barros, António Lucas Soares

\section{To cite this version:}

Dario Messina, Ana Cristina Barros, António Lucas Soares. An Information Management Perspective of Supplier Selection Process in Manufacturing Networks. 17th Working Conference on Virtual Enterprises (PRO-VE), Oct 2016, Porto, Portugal. pp.178-188, 10.1007/978-3-319-45390-3_16 . hal01614597

\author{
HAL Id: hal-01614597 \\ https://hal.inria.fr/hal-01614597
}

Submitted on 11 Oct 2017

HAL is a multi-disciplinary open access archive for the deposit and dissemination of scientific research documents, whether they are published or not. The documents may come from teaching and research institutions in France or abroad, or from public or private research centers.
L'archive ouverte pluridisciplinaire HAL, est destinée au dépôt et à la diffusion de documents scientifiques de niveau recherche, publiés ou non, émanant des établissements d'enseignement et de recherche français ou étrangers, des laboratoires publics ou privés. 


\title{
An Information Management Perspective of Supplier Selection Process in Manufacturing Networks
}

\author{
Dario Messina $^{1,2}$, Ana Cristina Barros ${ }^{2}$, António Lucas Soares ${ }^{1,2}$ \\ ${ }^{1}$ Faculty of Engineering, University of Porto, Portugal; ${ }^{2}$ INESC TEC, Porto, \\ Portugal
}

\begin{abstract}
The past decades have been characterized by an increasing interest of companies in international trade and significant foreign direct investments, which led to a shift from localized manufacturing companies to global manufacturing networks. The main goal of this research is to analyze the management of information within the process of supplier selection in the context of manufacturing networks. The adoption of field study methodology allows understanding how the supplier selection process is carried out in Multinational Companies (MNCs) in different manufacturing sectors. In particular, this paper aims at identifying the information that mother company and their subsidiary companies share during the supplier selection process, and how they access to this information.
\end{abstract}

Keywords: Manufacturing Networks, Supplier Selection Process, Information Management.

\section{Introduction}

Market globalization allows to broaden the potential base of customers worldwide but at the same time it leads to challenges in the management of suppliers and logistics. Moreover, the need for a quick reaction to the changes in demand, the decreasing production costs and the adoption of information and communication technologies (ICT) solutions leads to increasing level of uncertainty that organizations have to face [1-3].

Consequently, companies nowadays require increased efforts to manage their manufacturing plants from various locations and with different local requirements in order to maintain the service levels required by their customers $[4,5]$. This paper aims at contributing with new research at the intersection of information management and manufacturing networks fields of research. Manufacturing networks (MNs) are networks of production plants that are wholly owned by a mother company, i.e. all factories are under full financial control of the Multinational Company (MNC) [6].

The main goal of this research is to analyze the management of information within the process of supplier selection in multinational companies. Particular attention is given to the information acquisition phase and usage of external information in the 
whole process. The activities considered in the supplier selection process in this study are namely: problem formulation, formulation of criteria, supplier qualification, and final selection [7]. For what concern the information management it is considered to being composed by the following processes: information acquisition, organization, distribution and usage [8].

Specifically, this paper addresses the following research question: How is information managed in the supplier selection process of MNCs?

\section{Literature Review}

This section introduces the topics of manufacturing networks and information sharing for supplier selection process. In particular, it analyses the context of global sourcing in which manufacturing networks operate and evidences the trends that global sourcing has experienced in the last decades. The main drivers for the adoption of global sourcing and the most common integration mechanisms are identified. The second part of the literature review describes the supplier selection process and the importance of information sharing within this process.

Global sourcing

Manufacturing networks have their roots in the management of single manufacturing facility that has evolved to the management of several manufacturing facilities under the same overarching company [6]. The increasing interest on manufacturing networks and MNCs in general is linked with the internationalization of businesses. As environment becomes more complex and global, the management of an integrated international manufacturing network has become increasingly important for manufacturing managers [1]. Moreover, as manufacturing facilities of MNCs proliferate in the world, global sourcing has become a paramount function in these companies.

The adoption of global sourcing is not a new topic in management research field. It is possible to identify three waves that characterize the evolution of global sourcing in the last 30 years. Starting in the mid-' 80 s, firms showed an increasing interest in global sourcing related wit manufacturing activities [9]. Manufacturing firms start to look outside their local market in the search for more convenient sourcing opportunities abroad. Firms developed relationships with suppliers worldwide, mainly for raw materials and intermediate product, and consequently supply chains became more complex and global [10].

The '90s were characterized, substantially, by the growth of information technology (IT) departments that tried to respond to the complexity of organizational management. During these years firms considered IT departments as commodities, so outsourcing of this service to specialized providers was a common practice [11].

The third, and last, wave during the 2000 s is characterized by an increasing adoption of the outsourcing strategy, not only related to IT as in the "90s, but in general to all the activities that do not represent the "core" of the firm, such as human resources, finance, and sales, among others [11]. Also, the massive diffusion of 
Internet and related services challenged firms in the way they see their business [4, 12] and enabled new functions and services such as, e-procurement, e-commerce, or more in general the e-business.

Nowadays, global sourcing is the integration of purchasing units across the globe searching for products, processes, technologies, and suppliers [3]; or more in general global sourcing is defined as the management of the activities that a firm has to undertake to serve both local and foreign markets, from the selection of supplier base to the identification of the different products that have to serve the different markets [10].

Drivers of global sourcing

The primary objective of global sourcing is to improve performance, by reducing production costs, increasing the quality of the final product, allowing the identification of resources and skills not available in the own country, and being more flexible to changes in local markets [11]. Global sourcing allows companies to exploit both its own competitive advantage and that of its suppliers, by identifying countries that show peculiarities useful for global competition [10].

As the global sourcing strategy evolved during the years, also the motivation underlying its adoption changed accordingly. At the beginning, the main driver was represented by cost effectiveness [13] so firms operating in developed countries started to outsource their production in countries with lower labor costs, such as China and India. Once this trend was consolidated, the presence of occidental firms in oriental countries increased substantially, which lead companies to consider additional aspects, as for example new market entry, availability of infrastructures, exchange rate fluctuation, cultural environment, and ease of working with foreign governments $[1,10]$.

What was initially considered as an opportunity generated also new barriers for firms adopting this sourcing strategy. One of the main problems is related with cultural distances between firms and hosted countries, this distance has repercussions in terms of quality due to cultural and idiomatic misunderstanding. Another problem is linked with exchange rate fluctuation that led in some cases to considerable profit's erosion. To face this situation many companies, firstly the Japanese, start to replicate their supply chains in United States and Europe. In this way, the problem related to the need of being closer to customer's markets in order to respond promptly to changes at local base is also overcome.

Trautmann et al. [3] synthesize the three main motives for implementing global sourcing, namely economies of scale, economies of information, and economies of process. Economies of scale, allow to bundle volume of production across sites in order to decrease their unit cost [14]. Level of uncertainty is high, due to the interdependencies among actors. Economies of information, relate to the sharing of all relevant information, across different sites and location, on suppliers, new technologies, markets, internal users, etc. $[14,15]$. In this situation, the uncertainty is related to the limited availability of capable suppliers and the high heterogeneity of the offers. Finally, economies of process are related with the benefits derived from the establishment of best practices across different sites in different locations [14]. The uncertainty is relatively low, due to the standardization of processes across sites. The 
three kinds of economies are characterized by different organizational structures and integration mechanisms.

Organizational structures and integration mechanisms

Organizational structure is defined as the network of relationships that exists among various positions and position holders to reach a common goal [16]. It includes rules and procedures and other planned attempts to regulate organizational behavior. Figure 1 , shows a synthesis of the main organizational structures in which the circles with the "M" represent mother companies, while the other circles represent the network of subsidiaries regardless of their size, finally the lines identify the relationship between mother companies and their subsidiaries.

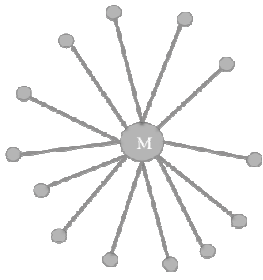

(a)

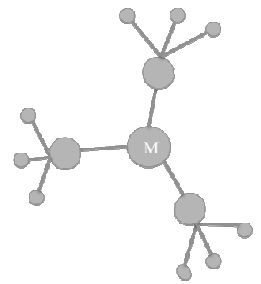

(b)

Centralized

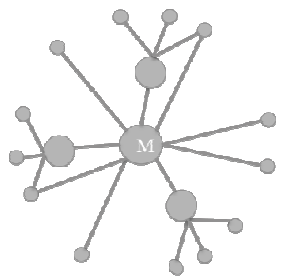

(c)

Decentralized

Hybrid

Figure 1: Organizational structures

Major organizational forms include: centralized, decentralized, and hybrid structures. Centralized structure, Figure 1 (a), is generally adopted in manufacturing networks, in which different geographical units buy similar products [3]. In this form, the organization is divided into functions.

Decentralized structure, Figure 1 (b), is implemented when individual firms of the manufacturing network produce unique or significantly different products [3]. In this case the organization is divided into organizational units (or divisions). In their research Mourtzis et al. [17] study a European automotive manufacturer, simulating the production based on real data considering both structures, centralized and decentralized. The results showed that decentralized structure is more flexible compared with centralized, and also allows to reduce costs and lead-times [17].

Lastly, hybrid structure, Figure 1(c), is adopted mostly in large multi-product organization, with the intention of managing in a most effective way the centralization-decentralization tradeoff [3]. At this purpose it maintain both functional and divisional partitions of the organization. A key challenge in this kind of structure is to distinguish between types of categories, to identify the ones with potential synergy and determining the most appropriate form of integration across geographical units [3, 14].

Once the organizational structure has been decided, firms belonging to the manufacturing networks need to identify the most suitable integration mechanism according to their goals. Integration mechanisms can be divided in two categories, namely vertical and horizontal integration. Each strategy has different implications for the internal relationships between parent companies and subsidiaries within the 
networks [2]. Figure 2 below presents the two integration mechanisms. As in Figure 1 , the circles with the " $M$ " represent the mother companies and the other circles stand for the subsidiaries. In this case, the arrows are representative of the decision-making flows that have to be followed to take the final decision, in both mechanisms.

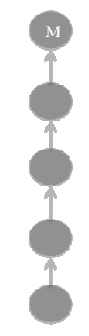

(a)

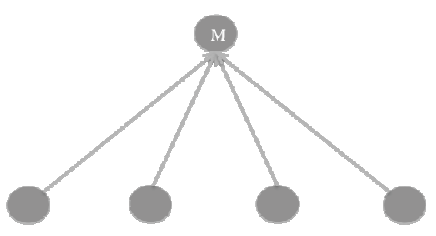

(b)

Vertical Horizontal

Figure 2: Integration mechanisms

Vertical integration, Figure 2 (a), is a hierarchical authority structure in which the different levels of the organization have different responsibilities [18]. It is generally adopted to gain control over the entire supply chain. It also can be implemented upstream or downstream, depending if the mother company gains control over its supplier or over its distributors, respectively. Conversely, horizontal integration, Figure 2 (b), is a mechanism in which organizations belonging to the network are characterized by similar abilities cooperate to accomplish specialized tasks or to integrate each other [16]. It is adopted to reduce the competition in a market. The combination of the different organizational structures and integration mechanisms allow to characterize the possible decision-making patterns that a decision maker needs to follow to consistently support the supplier selection process.

\section{Supplier selection process}

The relevance of purchasing function increased considerably in the last decades. Some authors consider supplier selection as the most important process within purchasing and supply management, taking into account its direct impact on the quality, cost and lead-time of new products, and technologies needed to meet new market demands [7, 19].

Recent trends in purchasing and supply chain management have further emphasized the relevance of selecting the right supplier. The increased adoption of outsourcing strategy has led to more firms spending a significant portion of their total revenue on externally sourced goods and services [20]. The trend towards supply base reduction increases the need of a more accurate supplier selection process in order to include only suppliers that can contribute positively to business performance improvement.

Within this context, several authors have provided decision-making models that support the decision makers in the supplier selection process [7, 21]. These authors 
recognize the relevance of adding pre-phases to the supplier selection process, towards improving the quality of the final supplier selection. In particular, the supplier selection process has four phases: problem formulation, formulation of criteria, qualification, and final selection [7, 19, 22]. A synthetic explanation of the four phases proposed by De Boer et al. [7] is provided next.

Problem formulation is related with the needs leading the network to the selection of a new supplier or the replacement of existing ones. During the formulation of criteria phase, the decision maker identifies the criteria to be used in the selection of suppliers, e.g. capacity, availability, quality, cost, and lead-time. Qualification phase is related with the sorting of the supplier base into a smaller group of potential candidates. The last phase is the final selection of the supplier or suppliers that, among the reduced group generated in the previous phase, present the higher ranking.

In manufacturing networks, the supplier selection process is a joint effort among the various production sites. Therefore, information sharing between network partners for new supplier selection plays an important role within this process.

\section{Information sharing}

If globalization allows to extend the selection of potential new suppliers worldwide, it also generates additional barriers to the integration and sharing of information [23]. These barriers may be characterized as legal, collaborative, organizational and informational. Legal constraints are related with the challenges due to the division of power among organizations and the adoption of information integration initiatives. Collaborative constraints refer to possible differences in terms of management that can obstacle cooperation and collaboration activities among partners. Organizational constraints are related with the need of business process standardization within the network. Finally, informational constraints are related with the different quality standards and possibility to share strategic information.

Information sharing is the action through which organizations share relevant, accurate, complete, and pertinent information with their partners, thus fostering connectivity with them and reducing information asymmetry [24-28]. The information shared can be grouped in two categories, namely internal and external information. Internal information, in this paper, is defined as any information present within the multinational, while external information is defined as any information that may be captured from outside the networks. Also, the distinction between internal and external is related with the means adopted to gather this information. External information may be gathered from institutional reports, stock market, public institutions, and consultancy reports, among others. Internal information is usually gathered from companies' IT systems, such as enterprise resource planning (ERP), electronic data interchange (EDI) or radio frequency identification (RFID) systems. The primary objective of information sharing is the improvement of network performance, since more visibility over others' operations lead to more informed and therefore better operational decision-making.

The decision-making models found in the literature [7, 19, 22, 23, 29], independently of the context of application and the approach (mathematical programming, rating/linear weighting, statistical etc.), take for granted that the information needed in the various steps of supplier selection process is available. This assumption is very strong because allows to overcome one of the major problem in 
real context, that is the need to have access to a conspicuous amount of valuable information to set the analysis. We consider information availability one of the focal point in all the information management process, independently from pursuing economies of scale, economies of information, or economies of process. For this reason, the analysis of how manufacturing networks have access to the information needed for supplier selection is an original aspect of this study.

\section{Methodology}

In this paper, the adoption of a decision making process contributes to understand how the information shared in manufacturing networks is organized. In particular, decision-making process is adopted with the purpose of supporting decision makers along the phases of supplier selection process.

Due to its exploratory nature, this work adopts field research [30]. In particular, case studies are developed in different manufacturing networks with subsidiary production plants installed in Portugal. Since the main purpose of this research is to understand how multinational companies in different sectors organize and share information among the network for supplier selection, the unit of analysis is considered at subsidiary level. The profiles of the interviewees are Purchasing or Procurement Managers. Data collection is carried out using semi-structured interviews at subsidiary companies, for a total of four interviews. Table 1 provides a summary of the empirical evidence gathered for the research.

Table 1: Companies data

\begin{tabular}{|c|c|c|c|c|c|c|c|}
\hline Sector & $\begin{array}{c}\text { Company } \\
\text { Code }\end{array}$ & $\begin{array}{c}\text { Year of } \\
\text { Foundation }\end{array}$ & $\begin{array}{l}\text { Company } \\
\text { Business }\end{array}$ & $\begin{array}{c}\begin{array}{c}\text { Number } \\
\text { of } \\
\text { Employees } \\
\text { of the } \\
\text { plant }\end{array} \\
\end{array}$ & $\begin{array}{l}\text { Number of } \\
\text { Production } \\
\text { Plants }\end{array}$ & $\begin{array}{c}\text { Supply } \\
\text { Chain } \\
\text { Positioning }\end{array}$ & $\begin{array}{c}\begin{array}{c}\text { Position of } \\
\text { the } \\
\text { Interviewee }\end{array} \\
\text {. }\end{array}$ \\
\hline Automotive & A & 1991 & $\begin{array}{l}\text { Mechanical } \\
\text { Locking } \\
\text { Systems } \\
\end{array}$ & 338 & 17 & $1^{\text {st }}$ Tier & $\begin{array}{l}\text { Purchasing } \\
\text { Manager }\end{array}$ \\
\hline Various & B & 1998 & Capacitors & 160 & 16 & $1^{\text {st }}$ Tier & $\begin{array}{c}\text { Procurement } \\
\text { Managers }\end{array}$ \\
\hline Automotive & $\mathrm{C}$ & 1994 & $\begin{array}{c}\text { Elastomeric } \\
\text { Components } \\
\text { manufacturer }\end{array}$ & 165 & 4 & $\begin{array}{l}1^{\text {st }} \text { Tier/ } \\
2^{\text {nd }} \text { Tier }\end{array}$ & $\begin{array}{l}\text { Purchasing } \\
\text { Manager }\end{array}$ \\
\hline Automotive & D & 2014 & $\begin{array}{c}\text { Internal } \\
\text { Combustion } \\
\text { Engine } \\
\text { components } \\
\end{array}$ & 720 & 56 & $1^{\text {st }}$ Tier & $\begin{array}{l}\text { Purchasing } \\
\text { Supervisor }\end{array}$ \\
\hline
\end{tabular}

The first aspect that stands out is related with the dimension of the firms belonging to the sample, in this case only Cases A and D can be classified as large business while Cases B and C are medium size business. The difference in terms of dimension is also associated with a broader coverage of different markets related with a massive presence of subsidiaries worldwide dispersed.

Only Case B operates in additional sectors aside the Automotive, such as Aerospace, Alternative Energy, and Telecommunication. All companies are 
positioning at Tier 1 level in the supply chain, except for Case $\mathrm{C}$ that is either Tier 1 or Tier 2 depending on their customers.

\section{Findings}

The research question leading this study is: How is information managed in the supplier selection process of MNCs? The results section is organized as follows: first, it presents how the supplier selection process is carried out in MNCs and which interactions exist between mother company and subsidiary, and second, it describes how information is managed in the supplier selection process in the context of a manufacturing network.

The results suggest a centralized organizational structure of the multinational companies with various levels of interdependency among partners along the supplier selection process. Companies A, B and C are vertically integrated while company D is horizontally integrated. Regarding this, companies A and B showed a higher level of dependency with headquarters during the whole process, while companies $\mathrm{C}$ and $\mathrm{D}$ are less dependent in terms of decision-making.

Taking into account the three steps of the supplier selection process namely, supplier identification, supplier evaluation, and supplier selection it was possible to identify that only companies $\mathrm{C}$ and $\mathrm{D}$ have complete autonomy, this level of autonomy allows them to be proactive in all the phases. On the contrary, companies A and $\mathrm{B}$ are involved in the first two steps, while mother companies are responsible for the final selection of new suppliers.

Another interesting aspect under analysis is the identification of the events triggering the need for a new or alternative supplier. Companies A and D showed a more strategic need for supplier selection process, while companies B and C more operational reasons. In particular, for company A the event leading to the adoption of a new supplier is related with the adoption of a new raw material for production, while for company $\mathrm{D}$ is related with the introduction of a new technology or the availability of new market skills. Instead, for companies B and $C$ the need of a new supplier is more related to its proximity with the existing plants, in order to be used as backup plants.

Considering now the information management aspect, the results are more homogeneous even if they present some difference in terms of the amount of information required to support the supplier selection process. For what concerns the information shared four categories were identified namely, demographics, skills and experience, market and clients, and process and tools. Figure 3 shows the categories and the related information shared collected during the interviews. 


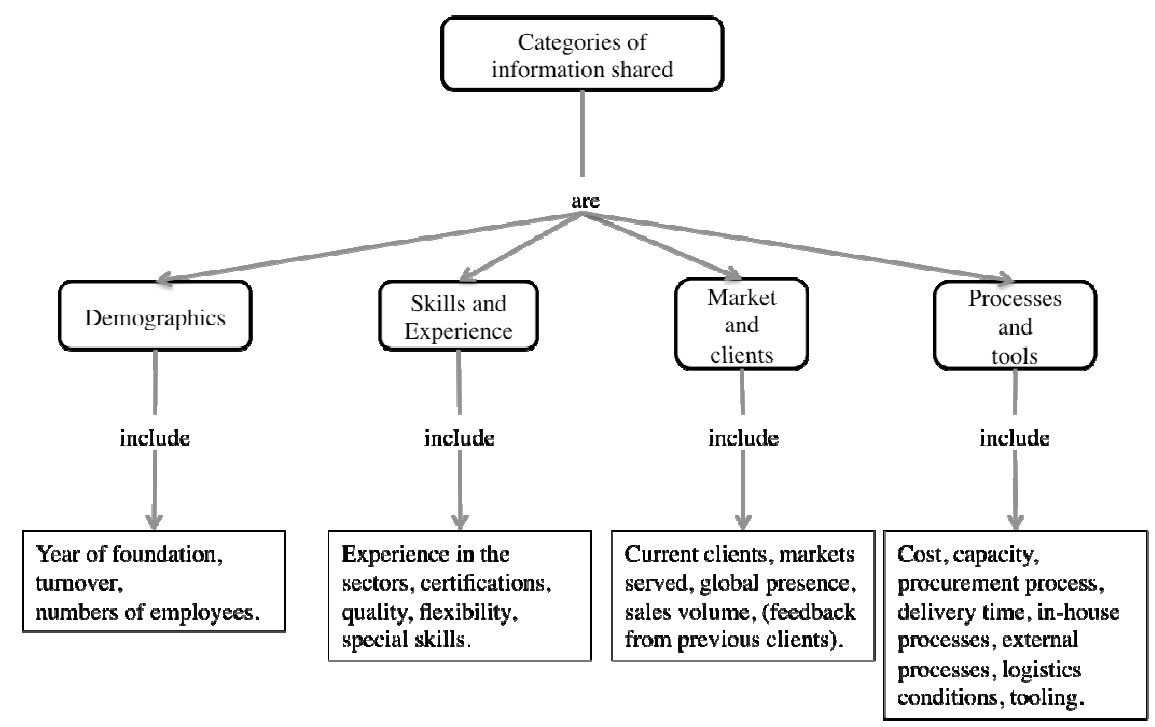

Figure 3: Categories of information shared

Table 2 summarizes the means used to gather and exchange the information shared among network members, external information is in bracket.

Table 2: Results of information gathering

\begin{tabular}{|c|c|c|c|c|}
\hline & Company A & Company B & Company C & Company D \\
\hline & & Visit/audit & \\
$\begin{array}{c}\text { Informatio } \\
\text { n Gathering } \\
\text { and } \\
\text { Exchange }\end{array}$ & $\begin{array}{c}\text { Visit/audit } \\
\text { plant, platform, } \\
\text { platform, ERP, } \\
\text { centralized } \\
\text { compliance } \\
\text { department }\end{array}$ & $\begin{array}{c}\text { Dropbox, } \\
\text { ERP, (public } \\
\text { events, } \\
\text { workshop, fair } \\
\text { etc.) }\end{array}$ & $\begin{array}{c}\text { Visit/audit } \\
\text { plant, platform }\end{array}$ & \\
\hline
\end{tabular}

Two aspects related to the information shared are the most relevant. Firstly, company B requires from their suppliers evidence related to the procurement of raw material. Company B adopts a procurement policy which contrast direct and indirect benefit of armed groups in poor countries. The second and most important aspect is related to the use of external information. Only company $\mathrm{C}$ declares the adoption of external information, in bracket in Figure 3, for the selection of new supplier. The drawback in this case is related with the fact that this information is the result of informal conversation in public events, and for this reason not systematized.

Regarding the information gathering, company B stated that the information is filtered by the presence of a centralized compliance department, that makes visible only the information relevant to the supplier selection process. Furthermore, contrary to the other cases company $\mathrm{C}$ is the only one that uses common means of information 
sharing, such as e-mail and Dropbox, instead of using a platform and/or ERP systems. The sole company satisfied with the performance of the actual information system is company $\mathrm{D}$, but this could be associated with the fact that company was founded only two years ago. The other companies have a longer activity in the sectors and highlighted some problems related with the information systems adopted. Companies $\mathrm{A}$ and $\mathrm{B}$ affirmed the frustration related to the absence of linkage between the platform and a series of additional databases that allow the make comparison between potential suppliers. On the contrary, company $\mathrm{C}$ declared the incompatibility of the ERPs systems adopted in the different plants, and the lack of a platform enabling the management of the information entered in the ERPs systems.

Concluding, an additional difference in terms of visibility has been found in the four companies. Particularly, company A is the only case that showed local visibility of the information entered into the platform, whilst mother company has global and total visibility. For what concerns company B, C and D, once the information is shared, this become visible to all the network members.

Based on the evidence collected in the field, was possible to characterize the supplier selection process in the context of MNCs and to identify the information that need to be provided to support the decision-making process.

\section{Conclusion}

This work contributes in presenting how the supplier selection process is currently carried out in manufacturing networks. This research also sheds light on how the sharing of information influences the decision-making process according to the different perspectives of mother company and subsidiary company.

The main limitation of the paper is related to the low number of cases considered in the study Even so, from the analysis of the data is possible to deduce a lack of use of external information as support to the selection process of new suppliers. It is not possible to determine whether this is due to an absence of interest from subsidiary companies in using external information as support, or whether it is due to the fact that missing the perspective of mother companies. A further development of the research could be extending the analysis including mother company managers, and additional manufacturing sectors such as Aerospace, and Semiconductors.

\section{References}

1. Rudberg, M., Martin West, B.: Global operations strategy: Coordinating manufacturing networks. Omega. 36, 91-106 (2008).

2. Shi, Y., Gregory, M.: International manufacturing networks-to develop global competitive capabilities. J. Oper. Manag. 16, 195-214 (1998).

3. TRAUTMANN, G., TURKULAINEN, V., HARTMANN, E., BALS, L.: Integration in the global sourcing organization - An information processing perspective. J. Supply Chain Manag. 45, 57-74 (2009).

4. Spina, G., Caniato, F., Luzzini, D., Ronchi, S.: Assessing the use of External Grand Theories in Purchasing and Supply Management research. J. Purch. Supply Manag. 
22, 18-30 (2016).

5. Rebolledo, C., Nollet, J.: Learning from suppliers in the aerospace industry. Int. J. Prod. Econ. 129, 328-337 (2011).

6. $\quad$ Rudberg, M., Olhager, J.: Manufacturing networks and supply chains: An operations strategy perspective. Omega. 31, 29-39 (2003).

7. $\quad$ De Boer, L., Labro, E. e Morlacchi, P.: A review of methods supporting supplier selection. Eur. J. Purch. Supply Manag. 7, 75-89 (2001).

8. Detlor, B.: Information management. Int. J. Inf. Manage. 30, 103-108 (2010).

9. Kotabe, M., Omura, G.S.: Sourcing strategies of European and Japanese multinationals: a comparison. J. Int. Bus. Stud. 113-130 (1989).

10. Kotabe, M., Murray, J.Y.: Global sourcing strategy and sustainable competitive advantage. Ind. Mark. Manag. 33, 7-14 (2004).

11. Kotabe, M., Murray, J., Mol, M.J.: GLOBAL SOURCING STRATEGY AND PERFORMANCE: A “'FIT”" VERSUS “'BALANCE”” PERSPECTIVE. Res. Glob. Strateg. Manag. 14, 259-278 (2008).

12. Spina, G., Caniato, F., Luzzini, D., Ronchi, S.: Past, present and future trends of purchasing and supply management: An extensive literature review. Ind. Mark. Manag. 42, 1202-1212 (2013).

13. Trent, R.J., Monczka, R.M.: International Purchasing and Global Sourcing-What are the Differences? J. Supply Chain Manag. 39, 26-36 (2003).

14. Trautmann, G., Bals, L., Hartmann, E.: Global sourcing in integrated network structures: The case of hybrid purchasing organizations. J. Int. Manag. 15, 194-208 (2009).

15. Faes, W., Matthyssens, P., Vandenbempt, K.: The Pursuit of Global Purchasing Synergy. Ind. Mark. Manag. 29, 539-553 (2000).

16. Teixeira, R., Koufteros, X., Peng, X.D.: ORGANIZATIONAL STRUCTURE, INTEGRATION, AND MANUFACTURING PERFORMANCE: A CONCEPTUAL MODEL AND PROPOSITIONS. J. Oper. Supply Chain Manag. 5, 69-81 (2012).

17. Mourtzis, D., Doukas, M., Psarommatis, F.: A multi-criteria evaluation of centralized and decentralized production networks in a highly customer-driven environment. CIRP Ann. - Manuf. Technol. 61, 427-430 (2012).

18. Zhang, D.: The Revival of Vertical Integration: Strategic Choice and Performance Influences. J. Manag. Strateg. 4, 1-14 (2013).

19. De Boer, L., Van Der Wegen, L.L.M.: Practice and promise of formal supplier selection: A study of four empirical cases. J. Purch. Supply Manag. 9, 109-118 (2003).

20. Luo, X., Wu, C., Rosenberg, D., Barnes, D.: Supplier selection in agile supply chains: An information-processing model and an illustration. J. Purch. Supply Manag. 15, 249-262 (2009).

21. Weber, C.A., Current, J.R., Benton, W.C.: Vendor selection criteria and methods. Eur. J. Oper. Res. 50, 2-18 (1991).

22. Wu, C., Barnes, D.: A literature review of decision-making models and approaches for partner selection in agile supply chains. J. Purch. Supply Manag. 17, 256-274 (2011).

23. Scholl, H.J., Kubicek, H., Cimander, R., Klischewski, R.: Process integration, information sharing, and system interoperation in government: A comparative case analysis. Gov. Inf. Q. 29, 313-323 (2012).

24. Li, S., Lin, B.: Accessing information sharing and information quality in supply chain management. Decis. Support Syst. 42, 1641-1656 (2006).

25. Legner, C., Schemm, J.: Toward the Inter-organizational Product Information Supply Chain-Evidence from the Retail and Consumer Goods Industries*. J. Assoc. Inf. Syst. 9, 119 (2008).

26. Cao, M., Vonderembse, M.A., Zhang, Q., Ragu-Nathan, T.S.: Supply chain 
collaboration: conceptualisation and instrument development. Int. J. Prod. Res. 48, 6613-6635 (2010)

27. Hung, W.H., Ho, C.F., Jou, J.J., Tai, Y.M.: Sharing information strategically in a supply chain: antecedents, content and impact. Int. J. Logist. Res. Appl. 14, 111-133 (2011).

28. Baihaqi, I., Sohal, A.S.: The impact of information sharing in supply chains on organisational performance: an empirical study. Prod. Plan. Control. 24, 743-758 (2013).

29. Kaipia, R., Hartiala, H.: Information-sharing in supply chains: five proposals on how to proceed. Int. J. Logist. Manag. 17, 377-393 (2006).

30. Meredith, J.: Building operations management theory through case and field research. J. Oper. Manag. 16, 441-454 (1998). 